\title{
Configurações
}

Revista de sociologia

\section{Through the looking-glass: a critical review of sociology and medicine towards the diagnosis of ADHD}

Através do espelho: uma revisão crítica das ciências sociais e médicas no caso do diagnóstico da PHDA

De l'autre côté du miroir : un examen critique de la sociologie et de la médecine vers le diagnostic du TDAH

\section{Ângela Marques Filipe}

\section{OpenEdition}

Journals

Édition électronique

URL : http://journals.openedition.org/configuracoes/916

DOI : $10.4000 /$ configuracoes. 916

ISSN : 2182-7419

Éditeur

Centro de Investigação em Ciências Sociais

Édition imprimée

Date de publication : 5 février 2011

Pagination : 73-86

ISSN : 1646-5075

Référence électronique

Ângela Marques Filipe, «Through the looking-glass: a critical review of sociology and medicine towards the diagnosis of ADHD », Configurações [En ligne], 8 | 2011, mis en ligne le 21 février 2013, consulté le 20 avril 2019. URL : http://journals.openedition.org/configuracoes/916 ; DOI : 10.4000/ configuracoes. 916

Ce document a été généré automatiquement le 20 avril 2019.

(c) CICS 


\title{
Through the looking-glass: a critical review of sociology and medicine towards the diagnosis of ADHD ${ }^{1}$
}

\author{
Através do espelho: uma revisão crítica das ciências sociais e médicas no caso do \\ diagnóstico da PHDA \\ De l'autre côté du miroir : un examen critique de la sociologie et de la médecine \\ vers le diagnostic du TDAH
}

Ângela Marques Filipe

1 In the last decades medicine assumed a central place within social sciences and research raising ethical, cultural, and clinical concerns with behavioral and mental health. In contemporary debates, one exemplary case where the relation between biological and sociological explanations has become highly complex and often controversial is attentiondeficit/hyperactivity disorder (ADHD). Public controversy around this diagnosis has now crossed the boundaries of the private and public, the family and school, the medical and the social. ADHD's possible underlying causes and the explanations provided with its diagnosis further seem to blur traditional dichotomies such as nurture - nature, culture biology, normal - pathological, and self - society. The most controversial issues around this particular diagnosis have to do with its etiology and treatment. On the one hand, there are different understandings of its causes opposing socialenvironmental and biological explanations and, on the other hand, there are concerns with over-prescription and adequacy of psychostimulant medication among children. Nonetheless while such discussions are being held and a massive amount of work has been published, the empirical examination of clinical and diagnostic practices and their ethical implications across countries has remained scarce.

2 In this article, attention-deficit/hyperactivity disorder will be deployed as an ancillary and heuristic case study for unraveling a complex relationship between fields of sociology and medicine. The first section depicts the makingof this disorder and its ordering as a diagnostic category. The following section portrays the medical and clinical debates 
around psychiatric diagnoses and categorization, as well as the singularities and issues concerning ADHD. Then, a brief overview of the founding critiques of psychiatry and medical sociology is presented discussing traditional propositions, notably the medicalization theory. Along those lines, important reconfigurations will be traced back into a wider hermeneutic and epistemological critique that puts into perspective the dialectics of the normal and the pathological as well as the real and the constructed.

In conclusion, the proposal of an 'anthroposcientific' approach aiming at recovering a plea which was left for a deeper collaboration between social and life sciences regarding the matters of human mind and behavior.

\section{Hypers and deficits: making the (dis)order}

4 ADHD is generally described as the most common child disorder reaching a worldwide estimated prevalence of $5 \%$ of school-age children (Polanczyk et al., 2007). The behavioral symptoms vary within inattention, hyperactivity or impulsiveness and are often accompanied by other developmental and psychiatric conditions such as learning, speech, and conduct disorders. ADHD diagnostic criteria may be found in the Diagnostic \& Statistical Manual for Mental Disorders (DSM), edited by the American Psychiatric Association, and in the fifth chapter of the International Classification of Diseases (ICD), published by the World Health Organization, even though the latter is mainly used in Europe (Singh, 2008).

The category ADHD went through diverse evolutions that manifest sociohistorical contingencies accompanying medical and psychiatric developments. This is particularly visible after the 1960s with emergence of the modern neurosciences (Cowan et al., 2000). Such evolutions became visible in the conceptualization and categorization of the disorder throughout various editions and revisions of the DSM. The first mention to any case resembling ADHD appeared in Charles Bradley's study (1937) where the calming effects of Benzedrine in children were reported. A decade after Strauss and Lethinen (1947) refer for the first time to a condition they named minimal brain damage. In the next decades and with the consolidation of child psychiatry, the development of cognitive scales and tests, and with experimental psychology, the category 'hyperkinesis' makes its entry in the second edition of the DSM published in 1968. The rating scales and behavior checklists continue to develop and by the 1970s Leo Kanner, the famous pediatrician who worked on autism, calls for a definition of minimal brain dysfunction, accompanied by the psychiatrist Paul Wender who pleas for the unification of the above mentioned descriptions (Lakoff, 2000).

6 Throughout the next decades neuropsychiatric research began paying attention to the organic causes of hyperkinesis which would be reframed as the inability to control impulses, shedding light on the difficulties of attention that pervaded the lives of those children. The attention-deficit disorder (ADD) and the three main behavioral criteria that subsist to the present - inattention, impulsivity, and hyperactivity - would be defined throughout the next decade and made their appearance in DSM's third edition (DSM-III). As noted by Allan Young the DSM-III marked a "diagnostic revolution" (1995) which, led by Robert Spitzer, sought to introduce a nosological consensus in the psychiatric practice. This was achieved mainly by a nomenclature of descriptive symptomatology allowing the unification of scientific and clinical research with biostatistics. 
7 This trend would consolidate in the 1990s with Russel Barkley's studies on the dysfunctions of inhibitory responses in the prefrontal cortex or Paul Wender's diagnosis of ADHD in adult populations, introduced in the fourth edition of the DSM (Wender, 1995).

8 It becomes clearer that the changing, enlarging, and multiplying scope of ADHD took its shape through diverse clinical, technical, and research practices: from neurobiology and the functional brain imaging to the developing industry of behavioral symptomatic checklists and scales, and importantly the effectiveness of the psychostimulant medication Methylphenidate. The current revised version of the DSM Fourth Edition, published in 2000, lists the criteria for an ADHD diagnosis that entails a disruptive, pervasive and/or impairing behavior or impact, dividing the disorder into three subtypes: Predominantly Inattentive Type; Predominantly Hyperactive-Impulsive Type; and, Combined Type (Singh, 2008).

In Portugal, ADHD is also listed as the major example of "Behavioral Disorders" in the official clinical recommendations for child and adolescent mental health (CNSM, 2009). In the Portuguese clinical literature ADHD is also reported to coexist with other psychological and developmental disorders, a prominent situation where around $60 \%$ of children presenting one or more overlapping diagnoses (Padilhão et al., 2009). Those frequently include oppositional defiant disorder, anxiety disorder and depression, obsessive-compulsive disorder, bipolar disorder, pervasive developmental disorder, dyslexia, and motor control disorders. Many of these forms of co-occurrence are usually encompassed by the clinical concept of comorbidity. In fact, one of the central features of the diagnosis of ADHD is a high comorbidity with other psychiatric and behavioural conditions in the vast majority of clinical cases (Rommelse et al., 2009).

\section{Diagnostic and clinical debates on ADHD}

Diagnosis is a rather central practice in clinical medicine and especially significant in cases such as ADHD. Here, a mix of developmental problems, moodiness, reading disabilities, emotional, and cognitive disorders, is frequently observed. The co-occurrence of an array of symptoms complicates the definition and practice of diagnosis and treatment of $\mathrm{ADHD}$, and at the same time, puts into stake the issue of etiology of the disorder. Facing that uncertainty some authors prefer to use alternative terminology, in effect a less clinical one, like co-occurrence, co-existence or overlap. And although some clinicians recognize that "a huge amount of effort goes into validating the diagnostic criteria of each edition of the DSM (...) there seems to be a growing concern among clinicians and researchers that the DSM diagnostic categories do not reflect the way in which these disorders affect real people" (Kaplan et al. 2001: 557). This is a debate linked to major diagnostic discussions taking place around ADHD and other psychiatric and behavioral 'conditions'.

11 In fact, questioning DSM's categorical definition of disorders, leaving behind their dimensional and clinical manifestation is a major point of tension in the milieu. In practice it entails that many people diagnosed with a mental disorder do not fit into DSM criteria and categories, even if it is the DSM that should fit their conditions and experience. And if complexity dominates the situation, the disparity between criteria and observation of conditions, it is even more visible and significant when it comes to 
disorders of children, testified in different clinical, epidemiological, and qualitative studies (Sundheim and Voeller, 2004; Lubke et al., 2009).

Moreover, in the DSM-IV the tonic on reliability gained over the component of validity. Steve Hyman (2007) reminds us also that such consensus and categorization do not mean inaccurate abstractions but rather the design of disorders boundaries as discrete and pure entities, that in reality and, especially, in clinical practice do not 'happen': symptoms, signs, primary and secondary diagnoses seem to overlap over and again. This is why the author draws our attention to potential novel classifications of mental disorders that could be indeed 'situation-based' and assume different models, for instance a dimensional perspective, an aggregation of symptoms in cluster or the inclusion of other continuum disorders or spectra, as it already happens with schizophrenia and autism. The criteria listed for certain diagnostic entities are in fact syndromical with nonspecific criteria, that is aggregates of clinical symptoms, which means multiple diagnoses will logically coexist.

In ADHD the term comorbidity, borrowed from clinical medicine, happens to be the rule rather than the exception. This is particularly puzzling in children and adolescents given the high variability of development (Voeller, 2004). As a comorbid disorder, ADHD appears as theoretically a worst-case scenario where only an impressive third of the cases constitutes 'pure ADHD' case (Kaplan et al., 2001). Comorbid ADHD overlaps not only diagnostic boundaries and disorder but also symptoms and subtypes, a situation that leads some clinicians to raise questions about the very definition this disorder (Schatz and Rostain, 2006), still centered in a behavioral triad of inattention, hyperactivity, and impulsivity.

14 In addition, the diagnosis of ADHD involves an striking multiplicity of agencies and mediations mainly parents, relatives, and teachers, as well as, advocacy groups, psychologists and social workers, and insurance companies, just to name a few. Behavioral rating scales, checklists, and reports of performance from familiar and scholar settings are necessary in ADHD's diagnostic process and the follow-up assessment. When it comes to child-patients of younger ages, a representative will be the one providing a medical history, and because ADH is a behavioral disorder, teachers will also be reporting the child's learning performance and exams' results. Clinicians will often spend time explaining to parents and relatives that ADHD is a brain dysfunction, not their blame or bad parenting, or encouraging teachers to see it as impairment of the child rather than a troublesome case. As noted by David Silverman (1987) in child disorders the social character of the clinic becomes even more visible.

\section{Medical sociology and the founding critiques of psychiatry}

15 Medical sociology had its inception in the structural-functionalist framework of sociology of the medical profession and medical representations. Starting with the conditions of possibility for the adoption of a 'sick-role' (Parsons, 1951) by the individual patient, the functions of both patient and professional would here gain terrain in the sociological analysis. Eliot Freidson (1970) in his 'sociology of applied knowledge' looked into aspects of uncertainty, professional pride, kinds of reasoning, and status quo. Howard Becker, with Strauss and his co-workers (Becker et al, 1961) would also conduct a study about the 
apprenticeship in teaching hospitals, focusing on the ways medical students learned skills other than their technical and medical expertise. In Boys in White the authors present an interesting analysis of non-medical learning and socialization inside the hospital complex.

In the early 1960s the critiques of psychiatry would emerge, even though from two very different points of view: Erving Goffman's Asylums: Essays on the Social Situation of Mental Patients and Other Inmates and Michel Foucault's Madness and civilization: a history of insanity in the age of reason. Goffman's seminal work marks the onset of a set of sociological studies inspired by symbolic interactionism, as coined by Herbert Blumer. Even though this was a highly diverse sociological perspective on how people interact it shed light on the ways they are constrained by social functions or structures while actively ascribing meaning to those interactions. In Asylums what we see pictured is the presentation of the self inside a total institution, in this case a mental hospital, where Goffman (1961) observed the ways the institutionalized individual presented himself as a docile individual. In the same year Foucault, who had developed his doctoral thesis on the theme of psychiatry, published his book on the history of madness. Through the genealogy of power and knowledge, a tradition in the French philosophical historiography, he was able to trace the subjective and political changes that brought the 'madness in the wild' to the contained walls of the asylum (2001 [1961]).

According to the first approach of traditional medical sociology and symbolic interactionism, a diagnostic category such as ADHD could result from several competing processes that include the social control of deviance, the superimposition of psychiatric categories, and the professionalization of medical doctors. From this point of view the process we are looking at is medicalization: "a process by which non-medical problems become defined and treated as medical problems, usually in terms of illnesses or disorders" (Gabe et al. 2004: 59). Further, medicalization encompasses discursive, institutional, and interactional elements leading to an extension of the boundaries of medicine into the boundaries of the non-medical (Conrad and Schneider, 1980). Hence, it could be argued that the rise of the diagnosis ADHD is the result of processes leading to a medical or 'psychiatrized' explanation of human distress and to the organization its practitioners. Therefore the extension of the diagnosis of ADHD may be accounted for in terms of trends such as the medicalization of human conduct and deviant behavior, as argued by Conrad (1975); the expansion of medical categorization (Conrad and Potter, 2000); and the neurologization of the mental health, as described by Rafalovich (2001; 2005).

18 In short the medicalization argument often corresponds to an idea that the pathological is gaining terrain at the expense of the normal through some actors, notably the 'medicalizing doctor': the diagnostician, the drug-prescriber, the insurance clinician, or the well-paid private practitioner. However, the rules of the game in medicine and mental illness changed dramatically in the last decades. To typify today's medical doctor as the agent of a medicalizing endeavour implies a rather utilitarian view of the clinical practice. The clinician, as the patient, user or client, may also be analyzed in his/her own terms: looking at the clinic through the clinical may provide us with a relevant perspective into the ways practitioners may remain conscious, concerned, and critical of diagnostic practices, classifications, and interventions. In light of traditional medical sociology, clinical and diagnostic practices have been analyzed in terms of medical organization and autonomy, rather than in terms of their substantive content and 
concern. If some authors advocate the crusade of moral entrepreneurship requires the development of professional services from doctors and psychiatrists (Becker, 1966); other authors such as Rose (1986) believe those accounts may obscure the complexities underlying psychiatric phenomena.

By reconstructing the paths across problematization, diagnosis and, intervention (Miller and Rose, 1994) we are able to adopt a more nuanced perspective on these issues, recalling the innovations taking place in the research and knowledge of the brain or the transformations of the political and social structures. These processes, among others and beyond medicalization, have slowly repositioned mental illness within the body while reconfiguring positive value of psychological wellness. In this way, rather than adopting one position or the other, that is, opting between 'rival schools' in social theory, in the above case interactionism and structuralism , this article follows Ian Hacking's proposal (2004) for an hermeneutic shift that allows me to sit between Goffman and Foucault.

\section{Is it real? Is that a disease? A pragmatist contribution to the sciences of man}

In Ludwik Fleck's essay On the Crisis of 'Reality' the author argues: “To observe, to cognize ( erkennen) is always to test and this literally to change the object of investigation. This is the day-to-day praxis of science." (1986 [1929]: 53). Practitioner of medicine and philosopher of science, Fleck had early understood and analyzed the constructive character of scientific and medical practice as process of knowledge-intervention: objects are not intrinsically objective but constructed as such. The epistemological analysis of the social construction of scientific knowledge has inspired other authors working with the social construction of medical knowledge and practice (Löwy, 1988; Mol, 2002). Medical sociology, medical anthropology, and cultural psychiatry have in such fashion provided analyses of the social construction of health and illness, particularly in the cases where diagnostic categories are said to be 'contested.' A contested diagnosis or illness is a condition whose nature or etiological root is argued to be, for example, dominantly social, psychiatric, or biological (Dumit, 2006). In this particular sense ADHD could be said to be a contested illness. But the question is often another.

Once a sociologist decides to take on the study of a case as ADHD one of the first questions he/she needs to answer is: is it real? On their side health professionals from clinical and developmental practices are faced with similar queries: is it a disease? (Fernandes, 2006). As noted by Ilina Singh: "Although there have been important efforts to deal theoretically with the biological dimensions of complex human behaviors in sociology, neither bioethics nor sociology has yet managed to fully take on the complexity of ADHD that is now widely accepted on the world of developmental and clinical child psychiatry" (2011: 889). Seconding this clarification, I will further sketch three brief lines of critique rooted in the epistemological and hermeneutic conviction that common dichotomies opposing the real and the constructed are not only more pervasive in sociology than usually acknowledged but also tend to overlook relevant aspects of their dialectic production.

First, questioning a phenomenon's realness does not imply a state of reality even though the question itself confuses both. When the question is posed as 'is the disorder real?' it doubts a phenomena's realness setting forth another truthful claim. Whether framed in terms of medical disorder or in terms of the individual's illness, a diagnostic category is 
not, in itself, real and true. Its realness and truthfulness are processes and not properties that are "realized in rebus", as noted by William James (1948 [1907]). To question if the disorder is real also brings to the fore the question of normativity. It implies a given judgment about what is real vis-à-vis the unreal, constructed, virtual, or artificial. In sum, the question 'is that disorder real?' lacks coherence, in the sense ascribed by George $\mathrm{H}$. Mead (1964 [1929]), and could be rephrased more accurately as 'is that disorder made up?'.

Second, questioning a phenomenon's reality would only be possible if we had set what is the real Real. The real reality, apart from the redundancy, is something incommensurable even though for some it remains the object of all knowledge. The point here is that when a researcher is asked if the disorder is real what underlies the question is a doubt on the reality of the disorder as opposed to an artificial disorder, that is, a manufactured entity. Not only this reifies the disorder itself, but also makes a presupposition that "(...) there is an important contrast between being a real disorder and being a product of social circumstances. The fact that a certain type of mental illness appears only in specific historical or geographical contexts does not simply that it is manufactured, artificial, or in any other way not real" (Hacking, 1995: 11-12).

Third, questioning whether a phenomenon is real, or unreal, brings about an -ism. Constructionism implies more than often ideas of manipulation, invention or intervention. Also, when this constructionist perspective is set forward by a sociologist as regards to a category of mental disorder, mental illness or abuse especially because these can be controversial categories, the terms 'construction' or the adjective 'real' are usually meant to appeal to the scepticism around those categories. As noted by Michael Lynch (1993) the term construction when similar to constitution does not imply an antonym, it is a constructive or constitutive view of social interaction which is phenomenologically informed. This is a view that seeks, I would argue, to depart from an excessive idealism that appeals to an essence of the real, a radical nominalism that appeals to a materialization of categories or a negative realism that only considers the existence of proved and palpable facts.

These three lines of critique set forth a pragmatist contribution to the debate although as recently proposed by sociologists of health and illness, the diversity, multiplicity, and complexity that have permeated medicine did it in such way we can no longer regard it as a monolithic structure (Berg and Mol, 1998). Thus, with contributions borrowed from cultural psychiatry, medical anthropology, and philosophy of science the focus of this article shifts onto the way praxis takes place and shape. Remarkable studies on medicine and psychiatry, their makings (Hacking, 1995) and formative practices (Good, 1994) have been developed in several fields that run parallel to sociology. Such contributions have also placed medicine back into the analysis of symbolic systems and historic-cultural backgrounds appealing to the need for grounded research in other national contexts and their local circumstances (Kleinman, 1988; Lakoff, 2005), hence setting the grounds for new critical perspectives on medicine and psychiatry.

A pragmatic but critical view of the diagnostic category ADHD draws our attention away from the debates of medicalization and elicits the processes and conditions leading us to consider a given child behavior as a diagnosed and treatable disorder. Authors such as Ilina Singh (2006, 2008 and 2011) have sought the empirical research and test of such formulations, through the children's voices and representations of their own diagnoses and medication intake. A number of clinicians, mental health nurses, and social workers 
have brought attention to the need of researching ADHD and its clinical practice in other national contexts (Schmitz et al., 2003; Wilcox et al., 2007). In a number of countries, as in Portugal, it is recognized that demanding and normalizing education systems have set standards which certainly invoke higher levels of failure from their students (Cordinhã and Boavida, 2008). These are questions that have been posed but remain broadly unanswered as they cross issues that imbricate in the very ways we have formulated our societies and certainly required highly complex answers.

As a productive and responsive avenue towards such complex questions, I propose the recovery of 'anthroposcience.' A striking but disregarded proposition from the famous Portuguese psychiatrist Barahona Fernandes who sought to have social, psychological, anthropological, medical, and psychiatric domains working in a close cooperation towards human health:

"What I have proposed for psychiatry and psychology in any medical setting was to be integrated with the cultural and social sciences aiming at a better understanding of the disordered man in the complex dialectics between health and illness. The plea left ... is for an integration of the collective [of the disciplines of Man] into what we might call anthroposciences" (Fernandes, 1984: 312).

In the past, similar interdisciplinary research agendas have been proposed and somehow disregarded. A good example that suits this article's theme was the proposition for a sociology of diagnosis by Phil Brown and Annemarie Jutel (Brown, 1990; Jutel, 2009).Yet it still left behind, I would argue, the potential lying at the very intersection of social and medical areas of expertise. Even if a tremendous amount of 'boundary work' (Bowker and Star, 1999) would be necessary convergence, instead of further sub-specialization, could then be sought. This appeal for the collaboration between social and life sciences further aims at displacing a homeostatic vision of human health that remains dominant into a new understanding of homeodynamics. Here, the human variations of normality, health or wellness may be evaluated in the individual's own terms and according to their perceived impact rather than any presupposed pathologization or categorical imposition (Canguilhem, 1991 [1957]). The quantitative and qualitative poles of the individual biology and the collective sociality should then be regarded as dynamic and relative or relational processes, wherein dialectic traces are left between vital processes of the organism and social interactions of the population: none is entirely 'the chicken or the egg'. This anthroposcientific approach allows both sociologists and clinicians to understand processes of disease less as a priori entities and more as individual and social 'telling' histories (Lima, 1946).

\section{Through the looking-glass: an anthroposcientific approach to diagnosis}

As psychiatry moved beyond the asylum walls into the community and contemporary societies, diagnosis and what counts as disorder, dysfunction, and pathology drifted away from a small but very acute number of situations, e.g. dementia praecox, to the present categorization of the DSM. It is my argument here that while a profound analysis and debate must take place in order to understand the grounds on which the entirety of human behavior is now encompassed by the psychiatric nomenclature, I reject any causal justifications describe the phenomena as a mere pathologization of normality. The biological and neuroscientific turns in medicine and psychiatry have, respectively, sought 
to localize mental disorder inside the human brain (Abi-Rached and Rose, 2010) while, simultaneously, clinical and diagnostic practices have incorporated new segments of the society (Armstrong, 2002), notably childhood and later life. The blurring of the normalpathological boundary is also strongly linked with to the widespread conceptions of psychoanalytical and dynamic views after the world war period, with mental health shifting from severe psychosis into milder forms of neurosis (Horwitz, 2002). Likewise it should be noted that biological psychiatry and neuroscience became large research agendas stirred not only by doctors, neurologists or psychiatrists but more importantly by psychologists, biomedical engineers, biostatisticians, pharmaceutical industries, insurance companies, and even patient advocacy groups. The encounters between the clinic and society through diagnosis have been influenced by exogenous technical transformations, such as the efforts in constituting international diagnostic guidelines in the clinical practice, and the endogenous epistemological shifts namely in medicine of children and pediatrics where the focus moved away from the presence of disease, as in clinical medicine, into normal growth and cognitive development (Armstrong, 1983).

Some would argue the power, dominance or autonomy of doctors relied on the advent of professionalization, bureaucratization, and specialization of the discipline and practice of medicine. Others would also recognize that such processes were fed by social demands as they ran parallel with scientific transformation.

Reconfigurations in national health politics; biostatics and epidemiology of mental illness; compulsory education and schooling organization; health campaigning, performance, and awareness; social and health movements; and advocacy patient groups have place, among many other elements in the transformation of the post-industrial liberal societies. With the rapid development of medical and psychological disciplines; the creation and consolidation of international classifications, accompanied by the research and technical breakthroughs in neuroscience, the conceptions of normal behavior and mental health have progressively been changed.

In the last decades, social scientists have argued the boundaries of the pathological have gained terrain at the expense of the normal human behaviour or the normal answers to different forms of distress and suffering. Doctors recognize there is a larger number of disorders and a larger number of diagnoses, which are directly linked to the expanding classification of the former and to improvements in the latter. In addition to the processual and categorical character of the diagnosis (Jutel, 2009) issues of technological, professional, and clinical relevance must be counted for. These aspects could be integrated with the social, historical, and cultural contingency moving "towards more complex models that allow for the interplay between the two, and view diagnosis as part of that interplay, nor separate from it" (Singh, 2011: 895).

By opening up this path in sociology and also in medical thought, we could make move away from a Cartesian reflection which only allows us to look in the mirror and produces divergence, towards a more nuanced and sophisticated critique of human mind and behavior. To approach this problematic I have suggested the renewal of a convergent style of thought: anthroposcience. 


\section{Acknowledgements}

34 A special word of gratitude goes to all the professionals who have shared with me their
for their intellectual support and generous supervision and my fellow researchers at CES.

\section{BIBLIOGRAPHIE}

ABI-RACHED, Joelle; ROSE, Nikolas (2010), "The birth of the neuromolecular gaze", History of the Human Sciences, 23, 1, 11-26.

ARMSTRONG, David (1983), Political Anatomy of the Body. Medical knowledge in Britain in the twentieth century, Cambridge, Cambridge University Press.

ARMSTRONG, David (2002), A New History of Identity: A sociology of medical knowledge, New York, Palgrave.

BECKER, Howard (1966), Outsiders. Studies in the sociology of deviance, New York, The Free Press.

BECKER, Howard; GEER, Blanche; HUGHES, Everett; STRAUSS, Anselm (1961), Boys in White: Student culture in medical school, Chicago, University of Chicago Press.

BERG, Marc; MOL, Annemarie (1998), Differences in Medicine: Unraveling practices, techniques, and bodies, London, Duke University Press.

BOWKER, Geoffrey; STAR, Susan Leigh (1999), Sorting Things Out: Classification and its consequences, Cambridge MA, MIT Press.

BRADLEY, Charles (1937), "The behavior of children receiving benzedrine", American Journal of Psychiatry, 94, 577-585.

BROWN, Phil (1990), "The name game: Toward a sociology of diagnosis", The Journal of Mind and Behavior, 11, 3, 385-406.

CANGUILHEM, Georges (1991 [1957]), The Normal and the Pathological, New York, Zone Books.

CNSM (2009), Recomendações para a Prática Clínica da Saúde Mental Infantil e Juvenil nos Cuidados de Saúde Primários, Lisboa, Coordenação Nacional para a Saúde Mental - CNSM/Ministério da Saúde. CONRAD, Peter (1975), “The discovery of hyperkinesis: Notes on the medicalization of deviant behavior", Social Problems, 23, 12-21.

CONRAD, Peter; POTTER, Deborah (2000), "From hyperactive children to ADHD adults: Observations on the expansion of medical categories", Social Problems, 47, 4, 559-582.

CONRAD, Peter; SCHNEIDER, Joseph (1980), "Looking at levels of medicalization: A comment on Strong's critique of the thesis of medical imperialism", Social Science and Medicine, 14A, 75-79.

CORDINHÃ, Ana Carolina; BOAVIDA, José (2008), “A criança hiperactiva: Diagnóstico, avaliação e intervenção”, Revista Portuguesa de Clínica Geral, 24, 577-589. 
COWAN, Maxwell; HARTER, Donald; KANDEL, Eric (2000), “The emergence of modern neuroscience: Some implications for neurology and psychiatry", Annual Review of Neuroscience, 23, 343-391.

DUMIT, Joe (2006), "Illnesses you have to fight to get: Facts as forces in uncertain, emergent illnesses", Social Science \& Medicine, 62, 577-590.

BARAHONA FERNANDES, Henrique (1984), A Psiquiatria em Portugal, Lisboa, Roche Farmacêutica. FERNANDES, José Boavida (2006), “Editorial: Hiperactividade ou má ‘educação'?”, Saúde Infantil, 28, 2, 3-5.

FLECKI, Ludwik (1986 [1929]), "On the crisis of "reality" in Robert Cohen and Thomas Schnelle (eds.) Cognition and Fact - Materials on Ludwik Fleck, Boston, D. Reidel Publishing Company, 47-57. FOUCAULT, Michel (2001[1961]), Madness and Civilization: A history of insanity in the age of reason, London, Routledge.

FREIDSON, Eliot (1970), The Profession of Medicine: A study of the sociology of applied knowledge, New York, Harper \& Row.

GABE, Jonathan; BURY, Mike; ELSTON, Mary Ann (2004), Key Concepts in Medical Sociology. London, SAGE Publications.

GOFFMAN, Erving (1961), Asylums: Essays on the social situation of mental patients and other inmates, New York, Anchor Books.

GOOD, Byron (1994), Medicine, Rationality, and Experience: An anthropological perspective, Cambridge, Cambridge University Press.

HACKING, Ian (1995), Rewriting the Soul. Multiple personality and the sciences of memory, New Jersey, Princeton University Press.

HACKING, Ian (2004), "Between Michel Foucault and Erving Goffman: Between discourse in the abstract and face-to-face interaction", Economy and Society, 33, 3, 277-302.

HORWITZ, Allan (2002), Creating Mental Illness, Chicago, Chicago University Press.

HYMAN, Steve (2007), “Can neuroscience be integrated into DSM-V?", Nature Reviews Neuroscience, $8,725-732$.

JAMES, William (1948 [1907]), Essays in Pragmatism, New York, Hafner Publishing.

JUTEL, Annemarie (2009), "Sociology of diagnosis: a preliminary review", Sociology of Health and Illness, 31, 2, 278-299.

KAPLAN, Bonnie; DEWEY, Deborah; CRAWFORD, Susan; WILSON, Brenda (2001), "The term comorbidity is of questionable value in reference to developmental disorders: Data and theory", Journal of Learning Disabilities, 34, 6, 555-565.

KLEINMAN, Arthur (1988), Rethinking Psychiatry: From cultural category to personal experience, New York, The Free Press.

LAKOFF, Andrew (2000), “Adaptive will: The evolution of attention deficit disorder", Journal of the History of the Behavioural Sciences, 36, 2, 149-169.

LAKOFF, Andrew (2005), Pharmaceutical Reason. Knowledge and value in global psychiatry, Cambridge, Cambridge University Press.

LIMA, Sílvio (1946), “Normal, anormal e patológico”, Biblos, 22, 113-161. 
LOWY, Ilana (1988), "Ludwik Fleck on the social construction of medical knowledge", Sociology of Health \& Illness, 10, 2, 133-155.

LUBKE, Gitta; HUDZIAK, James; DERKS, Eske; van BIJSTERVELDT, Toos; BOOMSMA, Dorret (2009), "Maternal ratings of attention problems in ADHD: Evidence for the existence of a continuum", Journal of the American Academy of Child and Adolescent Psychiatry, 48, 11, 1085-1093.

LYNCH, Michael (1993), Scientific Practice and Ordinary Action: Ethnomethodology and social studies of science, Cambridge, Cambridge University Press.

MEAD, George (1964 [1929]), Selected Writings, Chicago, University of Chicago Press.

MILLER, Peter; ROSE, Nikolas (1994), “On therapeutic authority: Psychoanalytical expertise under advanced liberalism", History of the Human Sciences, 7, 3, 29-64.

MOL, Anemarie (2002), The Body Multiple: Ontology in medical practice, Durham, Duke University Press.

PADILHÃO, Carla; MARQUES, Margarida; MARQUES, Cristina (2009), "Perturbações do comportamento e perturbação de hiperactividade com défice de atenção: Diagnóstico e intervenção nos Cuidados de Saúde Primários", Revista Portuguesa de Clínica Geral, 25, 592-599.

PARSONS, Talcott (1951), Toward a General Theory of Action, Cambridge, Harvard University Press. POLANCZY, Guilherme; LIMA, Maurício de; HORTA, Bernardo; BIEDERMAN, Joseph; ROHDE, Luís (2007), “The worldwide prevalence of ADHD: A systematic review and metaregression analysis", American Journal of Psychiatry, 164, 942-948.

RAFALOWICH, Adam (2001), "Psychodynamic and neurological perspectives on ADHD: Exploring stategies for defining a phenomenon", Journal for the Theory of Social Behavior, 31, 397-418.

RAFALOWICH, Adam (2005), "Exploring clinician uncertainty in the diagnosis and treatment of attention deficit hyperactivity disorder", Sociology of Health and Illness, 27, 3, 305-323.

ROMMELSE, Nanda; ALTINK, Marieke; FLIERS, Ellen; MARTIN, Neilson; BUSCHGENS, Cathelijne; HARTMAN, Catharina; BUITELAAR, Jan; FARAONE, Stephen; SERGEANT, Joseph; OOSTERLAAN, Jaap (2009), "Comorbid problems in ADHD: Degree of association, shared endophenotypes, and formation of distinct subtypes. Implications for a Future DSM", Journal of Abnormal Child Psychology, 37, 793-804.

ROSE, Nikolas (1986), "Psychiatry: The discipline of mental health" in Miller, Peter and Rose, Nikolas (1991), The Power of Psychiatry, Cambridge, Polity Press, 43-84.

SCHATZ, David; ROSTAIN, Anthony (2006), “ADHD with comorbid anxiety: A review of literature”, Journal of Attention Disorders, 10: 141-149.

SCHMITZ, Mark; FILIPPONE, Prema; EDELMAN, Elaine (2003) "Social representations of Attention Deficit/Hyperactivity Disorder, 1988-1997”, Culture Psychology, 9, 4, 383-406.

SILVERMAN, David (1987), Communication and Medical Practice: Social relations in the clinic, London, SAGE Publications.

SINGH, Ilina (2006), "A framework for understanding trends in ADHD diagnoses and stimulant drug treatment: Schools and schooling as a case study”, BioSocieties, 1, 4, 439-452.

SINGH, Ilina (2008), "Beyond polemics: Science and ethics of ADHD”, Nature Reviews Neuroscience, $9,12,957-964$.

SINGH, Ilina (2011), “A disorder of anger and aggression: Children's perspectives on attention deficit/hyperactivity disorder in the UK", Social Science \& Medicine, 73, 889-896. 
STRAUSS, Alfred and LETHINEN, Laura (1947), Psychopathology and the Education of the Brain-injured child, New York, Grune and Stratton.

SUNDHEIM, Suzanne; VOELLER, Kytja (2004), "Psychiatric implications of language disorders and learning disabilities: risks and management", Journal of Child Neurology, 19, 814-826.

VOELLER, Kytja (2004), “Attention-deficit hyperactivity disorder (ADHD)”, Journal of Child Neurology, 19, 798-814.

WENDER, Paul (1995), Attention-deficit Hyperactivity Disorder in Adults, New York, Oxford University Press.

WILCOX, Claire; WASHBURN, Rachel; PATEL, Vikram (2007), "Seeking help for attention deficit hyperactivity disorder in developing countries: A study of parental explanatory models in Goa, India", Social Science \& Medicine, 64, 1600-1610.

YOUNG, Allan (1995), The Harmony of Illusions. Inventing post-traumatic stress disorder, New Jersey, Princeton University Press.

\section{NOTES}

1. The paper was drawn from work developed within the author's doctoral project in Sociology funded by the Science and Technology Foundation (SFRH / BD / 68492 / 2010 POPH - QREN).

\section{RÉSUMÉS}

Durant les dernières décennies, le domaine de la médecine a pris une place centrale dans les sciences sociales, en particulier en Europe et en Amérique du Nord. L'analyse de la prédominance professionnelle des médecins, de la médicalisation des relations sociales et de la catégorisation psychiatrique du comportement a contribué à l'émergence de la sociologie et de l'historiographie de la médecine. La critique de la psychiatrie et de ses catégorisations du comportement humain met en jeu la manière dont nous sommes venus à considérer non seulement la santé et la maladie, mais aussi ce qui est perçu comme un comportement normal ou pathologique. Le diagnostic du trouble du déficit de l'attention avec hyperactivité [TDAH] illustre la relation complexe qui existe entre les explications biologiques et sociologiques. Cet article prend pour étude de cas le TDAH pour revoir de manière critique la relation entre sciences sociales et sciences de la vie qui demeure encore souvent nébuleuse. Cette critique prend aussi place dans les débats herméneutiques et épistémologiques qui concernent certaines dichotomies comme le réel et le construit ou le normal et le pathologique. En conclusion, l'article suggère un réexamen de la recherche à la fronteire de la sociologie et la médicine en s'inspirant d'une perspective 'anthroposcientifique'.

In the last decades the domain of medicine assumed a central place within social science debates, particularly in Europe and North-America. Analyses of the professional dominance of medicine, the medicalization of sociality, and the categorization of deviance as psychiatric condition were at the onset of medical sociology and historiography. Such critiques aimed at shedding light on 
the ways we have come to consider not only what is health and illness but also what counts as normal or pathological behavior. In this sense, cases such as attention-deficit/hyperactivity disorder [ADHD] exemplify a complex relation between biological and sociological explanations of human behavior. The paper looks at ADHD diagnosis as a heuristics for the critical review of the relationship between social and life sciences. That relationship, often thorny, will be then articulated with a wider hermeneutic and epistemological critique of the real and the constructed, the normal and the pathological, and their reconfigurations. In conclusion, a plea will be left with the intent of debunking conventional suspicions of sociology with regards to medicine through the recovery of an 'anthroposcientific' perspective.

Nas últimas décadas o domínio da medicina assumiu um lugar central nos debates em ciências sociais, nomeadamente na Europa e América do Norte. A análise da dominação da medicina, da medicalização da socialidade ou mesmo da categorização do desvio como condição psiquiátrica estiveram na origem da sociologia e historiografia médica. Estas críticas procuraram esclarecer o modo pelo qual pudemos não só delimitar o que é considerado como saúde e doença mas também o que é comportamento normal ou patológico. Nesta linha de análise, casos controversos como os da perturbação de hiperactividade com défice de atenção [PHDA] vêm apontar para uma complexa relação biologia-sociedade, assim como para a dificuldade em separar aqui argumentos biológicos de argumentos sociais e culturais do comportamento humano. Este artigo aborda o caso de estudo da PHDA e do seu diagnóstico como modelo heurístico com vista a um entendimento crítico sobre a relação entre sociologia e medicina. Esta relação, muitas vezes conturbada, surge neste sentido como parte de alguns posicionamentos hermenêuticos e epistemológicos mais amplos, por exemplo sobre o real e o construído, o normal e o patológico, e as suas reconfigurações. Finalmente, apela-se reconsideração da postura de ambos os campos de conhecimento através da recuperação duma proposta ou perspectiva 'antropocientífica'.

\section{INDEX}

Mots-clés : le TDAH, sociologie, la médecine, diagnostic, anthroposcience

Palavras-chave : PHDA, sociologia, medicina, diagnóstico, antropociência

Keywords : ADHD, sociology, medicine, diagnosis, anthroposcience

\section{AUTEUR}

\section{ÂNGELA MARQUES FILIPE}

Department of Sociology, London School of Economics and Political Science, UK. Angela Marques Filipe is a PhD candidate at the Department of Sociology, London School of Economics, visiting scholar at the King' College, and an assistant researcher at the Centre for Social Studies, University of Coimbra, Portugal, a.m.filipe@lse.ac.uk.

en 